\title{
Investigating retroviral super-infection in wild chimpanzees (Pan troglodytes verus)
}

\author{
Anja Blasse $^{1 *}$, Adeelia Goffe ${ }^{1}$, Roger Mundry ${ }^{2}$, Fabian H Leendertz', Sébastien Calvignac-Spencer ${ }^{1}$ \\ From 15th International Conference on Human Retroviruses: HTLV and Related Viruses \\ Leuven and Gembloux, Belgium. 5-8 June 2011
}

\section{Background}

While the molecular epidemiology of retroviruses in wild primate populations has received much attention, the related question of the frequency and nature of super-infection events has remained largely neglected. Here, we explicitly investigated it, focusing on simian foamy viruses (SFV) infecting wild chimpanzees (Pan troglodytes verus), as an example.

\section{Methods}

We first compared the costs and benefits of end-point dilution PCR (EPD-PCR) (currently considered a gold standard method) and multiple bulk PCR cloning, when applied to non-invasive samples. For the latter method, we had to develop a specific analytical framework aimed at deciphering relevant biological information from method-induced biases. We then applied multiple bulk PCR cloning to samples collected from chimpanzees belonging to different age classes.

\section{Results and discussion}

We found that, when applied to faeces, proper EPDPCR analysis will sometimes require the consumption of unrealistic large amounts of biological material (i.e. when "native" EPD-PCR conditions are encountered). However, super-infection status, as well as the underlying main strain sequences, could be robustly inferred from multiple bulk PCR analyses (which are more parsimonious), using a combination of statistic and network analyses. Applying this method to individuals belonging to different age classes, we finally found that wild chimpanzees actually accumulated distinct chimpanzee-specific SFV throughout their lives.

\footnotetext{
* Correspondence: blassea@rki.de

${ }^{1}$ Research group Emerging Zoonoses, Robert Koch-Institut, Berlin, Germany
} Full list of author information is available at the end of the article

\section{Author details}

${ }^{1}$ Research group Emerging Zoonoses, Robert Koch-Institut, Berlin, Germany.

${ }^{2}$ Max Planck-Institute for Evolutionary Anthropology, Leipzig, Germany.

Published: 6 June 2011

doi:10.1186/1742-4690-8-S1-A242

Cite this article as: Blasse et al.: Investigating retroviral super-infection

in wild chimpanzees (Pan troglodytes verus). Retrovirology 2011 8(Suppl 1):A242.
Submit your next manuscript to BioMed Central and take full advantage of:

- Convenient online submission

- Thorough peer review

- No space constraints or color figure charges

- Immediate publication on acceptance

- Inclusion in PubMed, CAS, Scopus and Google Scholar

- Research which is freely available for redistribution

\section{() Biomed Central}

